\title{
A Virtual-Reality Edu-Game: Saving The Environment from the Dangers of Pollution
}

\author{
Dita Aluf Mawsally*, Endah Sudarmilah \\ Program Studi Informatika \\ Universitas Muhammadiyah Surakarta \\ Surakarta, Indonesia \\ *Ditaaluf11@gmail.com
}

\begin{abstract}
Our virtual reality educational game -themed "saving the environment from the dangers of pollutions"- aims to help children aged 10-13 years in learning about pollution and its reduction. This game uses smartphone and VR Box. This edu game is designed using the SDLC (Software Development Life Cycle) model of the waterfall model. Assets contained in this game are obtained from the Unity Asset Store which will simulate learning techniques with several educational games. This can be seen as a development from the traditional learning method. Based on a black box test, this game runs well on the target device. On the usability test using the System Usability Scale (SUS), this game gets a score of 71.58 which is in the "good" criteria.
\end{abstract}

Keywords: Educational Games, Pollution, Virtual Reality

\section{Introduction}

The rapid development of Information Technology drives many people to use applications as tools to facilitate their daily work, as entertainment gadgets, and even educational devices. Utilization of smartphones for use in various fields is done by developing applications that support activities in that field. The same thing happens in the field of education, which uses smartphones as learning media [1]. Learning using digital media must still pay attention to the curriculum, materials, methods, and students' learning abilities in achieving learning goals in school [2].

Learning media always follow the development of existing technology, such as 3D animation or science fiction films, which make technology more interesting and interactive [3]. One particularly popular technology right now is virtual reality educational games that are loved by children, adolescents, and even adults [4]. Virtual reality devices depicts a three dimensional environment constructed by computers in such a way that it the devices can interact with the users [5]. Our VR-based educational game, named "Earth Hero", makes users feel the VR experience by combining gyroscope-equipped mobile devices with Google Cardboard and VR Box. VR technology is useful in the fields of education, property, medicine, transportation, architecture, entertainment, etc. [6].
The theme "saving the environment from the dangers of pollution" was chosen because many human behavior intentionally or unintentionally cause pollution on earth. Pollution is a threat that can damage the ecosystem of terrestrial and marine life. Air pollution, or changes in the composition of the air element from normal conditions, can result in changes in temperature and damages to the environment [7].

The adverse effects of air pollution and water pollution for human health cannot be refuted anymore. Marine pollution has long been recognized as a threat to the growth of marine biota [8]. This educational game, called "Earth Hero", was created to simulate learning methods in the classroom related to the environment. It is hoped that students will be more aware of the impacts and dangers of pollution so they can better maintain the cleanliness of the environment and the earth.

\section{Method}

This study aims to design VR-based educational games as learning media for elementary school students aged 10 to 13 years, namely grades 4 to 6 elementary school. This game was built using the SDLC (Software Development Life Cycle) method [9], [10]. The system development is done in order, starting from the requirement analysis, design, coding, testing, and implementation [11]; as shown in Figure 1. 


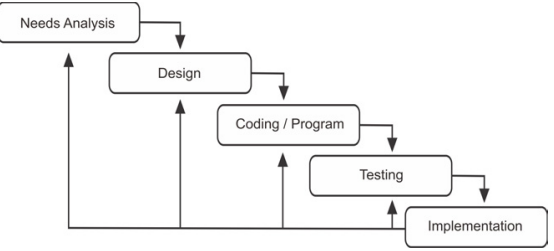

Figure 1. Flowchart of research system flow

\section{a. Requirement Analysis}

Hardware and software requirements needed in making the game "Earth Hero" are presented in Table 1.

Table 1. Hardware and Software Needs

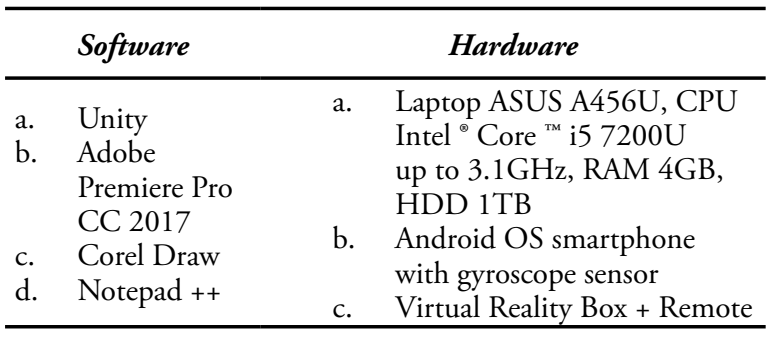

\section{b. Design}

Table 2. Game storyboards

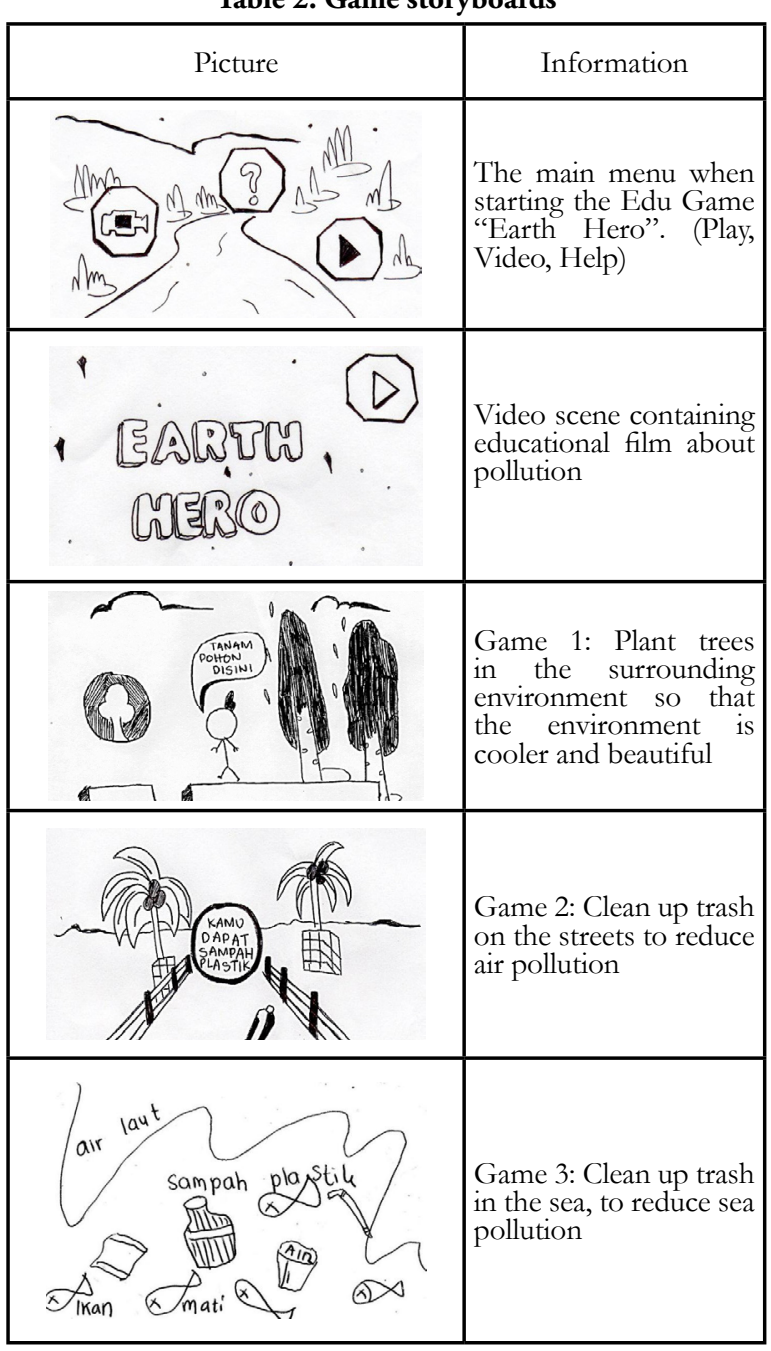

The design stage is an advanced stage after the analysis stage where the story board is drawn and various things such as assets, music, sound, and video are assembled. Table 2 shows the storyboard.

\section{c. Coding}

Some code is used to control assets and scenes. Among them are codes for movement, movement, up and down, and disappearing. The programming language used is C\# and written using Notepad++ code editor [12].

\section{d. Testing}

Testing is the final stage after the application is complete. The application is tested to find out if this program can be accepted by the user and to ensure that there are no errors in the application and there are no difficulties felt by the user when playing the game. The test method used is the black box test and the reusability test [13].

\section{e. Implementation}

The last stage of SDLC is the implementation of the game in the hope that the results will be good and in accordance with the initial objectives [14]. At this stage there was also an observation of the use of the application when played by respondents who participated in the test.

\section{Results}

This research resulted in an VR-based educational game "Earth Hero - Save the Earth from Pollution" that can help students learn in an effective and fun way.

\section{a. Game Start Page}

The initial appearance of the game is designed with 3 main buttons, namely the video, play, and help buttons which can be seen in Figure 2 .

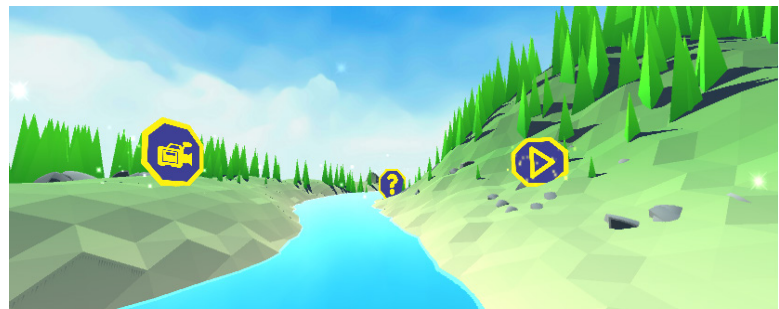

Figure 2. Initial Display of the Game

The game's display of the menu section - when viewed using an android smartphone with a gyroscope sensor accompanied by special tools - is shown in Figure 3.

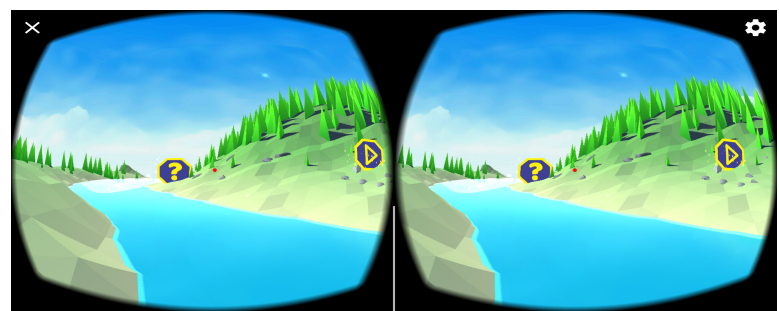

Figure 3. Menu display when viewed on a smartphone with certain capabilities. 


\section{b. Educational Video}

Videos are added to present new experiences in learning. There are several obstacles in video development. Among them are the limited time the teachers have to develop the media and the lack of mastery of video editing software [15]. To help teachers, relevant educational videos are added in this application. When pressing the video button on the start menu, one will see a 2 minute video as depicted in Figure 4.

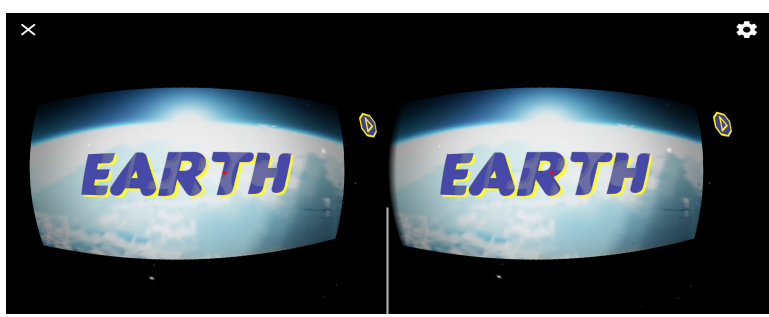

Figure 4. The educational video when playing on a VR-abled smartphone

In the video menu display, there is a play button which if the reticle pointer is directed for 2 seconds (clicked), will bring the player into Game 1. The button can be clicked at any time: when finished watching the video, in the middle of the video running, or in the beginning of the video.

\section{c. Game 1}

The player is tasked with planting trees around the park environment to increase oxygen so that air pollution caused by vehicle fumes can be reduced. This game is done by players who will walk around the park and find the button to plant trees. If the tree has been planted, a pop up will appear containing an educational message in the Game 1 environment as shown in Figures 5, 6, and 7.

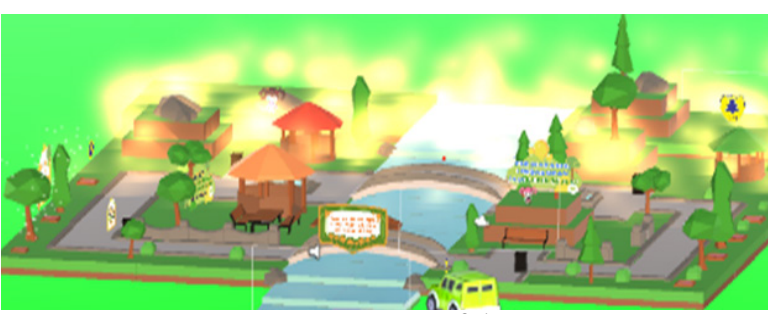

Figure 5. Environment of the Game 1

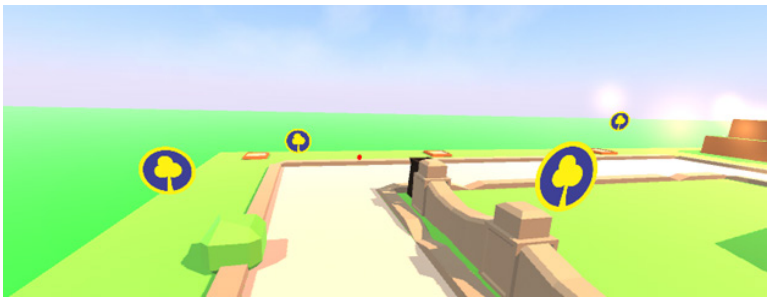

Figure 6. Blue button for planting trees

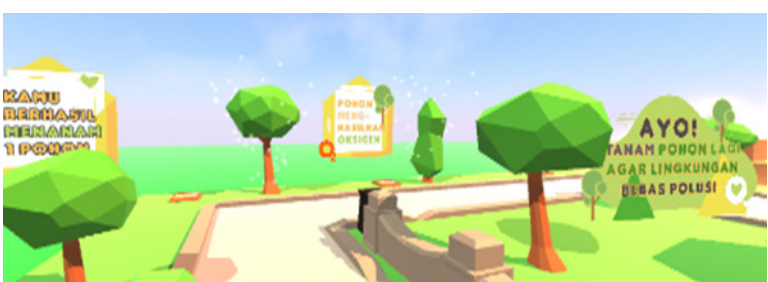

Figure 7. Trees that have been planted and the corresponding pop up.

\section{d. Game 2}

The player is tasked with picking up trash on the road so that the road is clean from rubbish and so that soil pollution is reduced. When the player passes the trash, the player will pick it up and an educational popup appears. The game's Display 2 can be seen in Figures 8 and 9.

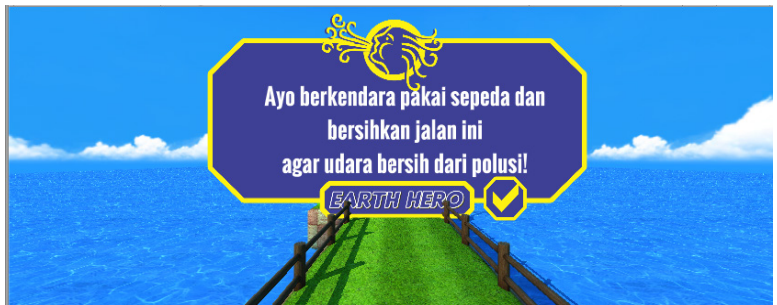

Figure 8. Initial entry into Game 2

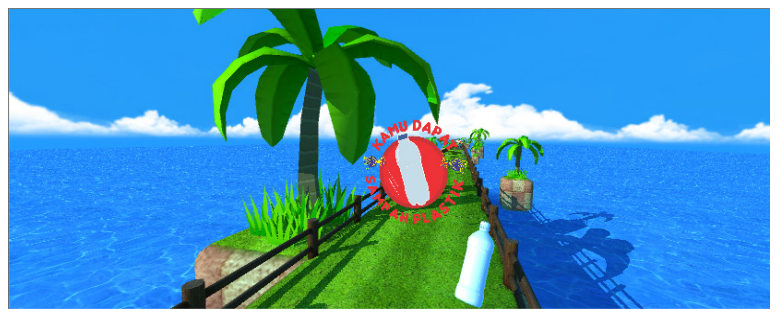

Figure 9. Garbage to be taken in Game 2

\section{e. Game 3}

The task of the players in Game 3 is to pick up trash from the sea that aims to reduce marine pollution and prevent the extinction of the marine ecosystem. When the player passes the trash, the player will take it until the sea environment is clean.

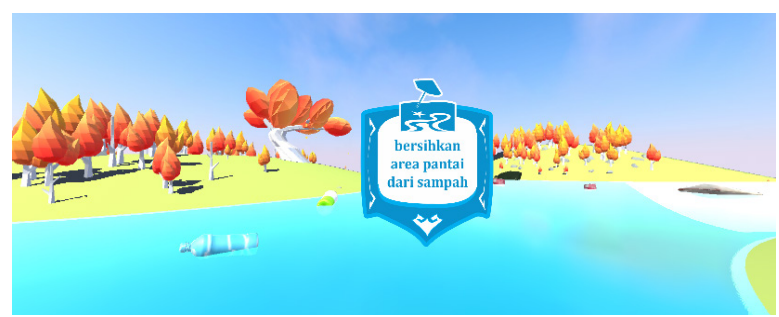

Figure 10. Game Display 3

\section{Discussion}

\section{a. Application Testing}

Testing is the final stage after the application is complete. The user tests whether the application can be accepted and to ensure that there are no errors and no difficulties felt by the user when running the application. Black box testing is carried out on several user interfaces, sound, and controls in the game, as well as testing on smartphones [16]. The focus of the black box test on the main features of the system is done to find functions that are not running properly, interface errors, errors in data structures and database access, performance errors, and initialization / termination errors [17], [18]. Tests was carried out using an Android smartphone branded Nougat Oppo type F5. The test results show that the "Earth Hero" application can run well on the target device. 


\section{b. Usability Test}

Usability Test is done by observing the object when running the application and recording events when the object encounters an error in the application that [19]. The test was conducted on 30 elementary school students aged 10-13 years by demonstrating the game which is played using VR Box and an Android smartphone. The assessment system uses the System Usability Scale (SUS), which is a questionnaire to measure the usability of a computer system according to the user's subjective point of view. SUS was developed by John Brooke since 1986 and is still often used today. Respondents were asked to give an assessment of the system starting from "Strongly disagree", "Disagree", "Neutral", "Agree", and "Strongly agree" on the 10 items SUS statement. Each statement item has variables R1 through R10 [20] [21]. The overall SUS score is obtained from the average individual SUS score using the following Equation 1 formula:

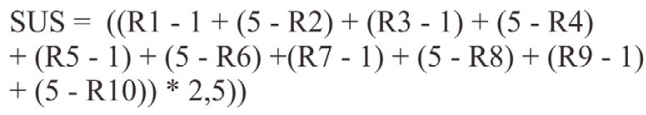

Table 3 is the results of questionnaire data usability test using SUS formula calculation with statement criteria: 1 : I love Edu Game Earth Hero so I will play it many times.

2 : In my opinion Edu Game Earth Hero is too complicated to play.

3 : I think Edu Game Earth Hero is easy to use

4 : I need help from others to play Edu Game Earth Hero

5 : I consider Edu Game Earth Hero parts to be played well

6 : I think the way to play Edu Game Earth Hero is confusing

7 : I think other people will learn to play Edugame Earth Hero very quickly

8 : I consider Edu Game Earth Hero impractical (difficult) to play

9 : I feel that I can play Edu Game Earth Hero

10 : I need to learn a lot to be able to play Edugame Earth Hero

Table 3. Calculation results with the SUS formula

\begin{tabular}{|c|c|c|c|c|c|c|c|c|c|c|c|c|}
\hline \multirow{2}{*}{$\begin{array}{c}\text { Respondent } \\
\text { Number }\end{array}$} & \multicolumn{10}{|c|}{ Item Question } & \multirow{2}{*}{ Total } & \multirow{2}{*}{$\begin{array}{c}\text { SUS Score } \\
(\text { Total * 2.5) }\end{array}$} \\
\hline & 1 & 2 & 3 & 4 & 5 & 6 & 7 & 8 & 9 & 10 & & \\
\hline 1 & 3 & 4 & 3 & 3 & 3 & 4 & 3 & 4 & 4 & 3 & 34 & 85 \\
\hline 2 & 3 & 3 & 4 & 1 & 3 & 3 & 4 & 4 & 4 & 1 & 30 & 75 \\
\hline 3 & 2 & 0 & 4 & 0 & 3 & 2 & 4 & 1 & 4 & 4 & 24 & 60 \\
\hline 4 & 4 & 3 & 3 & 4 & 4 & 3 & 3 & 4 & 3 & 2 & 33 & 82.5 \\
\hline 5 & 2 & 2 & 2 & 1 & 2 & 2 & 0 & 2 & 2 & 2 & 17 & 42.5 \\
\hline 6 & 4 & 3 & 2 & 2 & 3 & 2 & 4 & 4 & 3 & 2 & 29 & 72.5 \\
\hline 7 & 1 & 3 & 3 & 1 & 3 & 1 & 3 & 3 & 3 & 1 & 22 & 55 \\
\hline 8 & 3 & 2 & 3 & 0 & 4 & 4 & 4 & 4 & 4 & 1 & 29 & 72.5 \\
\hline 9 & 4 & 4 & 4 & 4 & 4 & 4 & 4 & 4 & 4 & 4 & 40 & 100 \\
\hline 10 & 4 & 4 & 4 & 4 & 4 & 4 & 4 & 4 & 4 & 1 & 37 & 92.5 \\
\hline 11 & 4 & 3 & 4 & 3 & 4 & 3 & 4 & 3 & 4 & 0 & 32 & 80 \\
\hline 12 & 4 & 4 & 2 & 0 & 3 & 3 & 2 & 2 & 3 & 2 & 25 & 62.5 \\
\hline 13 & 2 & 1 & 2 & 1 & 2 & 3 & 1 & 3 & 2 & 0 & 17 & 42.5 \\
\hline 14 & 4 & 4 & 4 & 0 & 4 & 0 & 0 & 4 & 4 & 4 & 28 & 70 \\
\hline 15 & 3 & 4 & 3 & 2 & 4 & 4 & 2 & 4 & 3 & 2 & 31 & 77.5 \\
\hline 16 & 4 & 4 & 4 & 4 & 4 & 4 & 4 & 4 & 4 & 4 & 40 & 100 \\
\hline 17 & 2 & 4 & 3 & 2 & 3 & 4 & 2 & 4 & 4 & 4 & 32 & 80 \\
\hline 18 & 4 & 2 & 3 & 1 & 4 & 1 & 0 & 0 & 0 & 2 & 17 & 42.5 \\
\hline 19 & 4 & 4 & 4 & 3 & 3 & 4 & 4 & 4 & 4 & 0 & 34 & 85 \\
\hline 20 & 3 & 3 & 2 & 3 & 2 & 3 & 2 & 1 & 3 & 2 & 24 & 60 \\
\hline 21 & 4 & 4 & 4 & 4 & 4 & 4 & 4 & 4 & 4 & 4 & 40 & 100 \\
\hline 22 & 2 & 3 & 3 & 3 & 3 & 2 & 3 & 4 & 3 & 2 & 28 & 70 \\
\hline 23 & 3 & 1 & 2 & 1 & 4 & 3 & 4 & 4 & 3 & 1 & 26 & 65 \\
\hline 24 & 4 & 3 & 4 & 3 & 4 & 5 & 3 & 4 & 3 & 2 & 35 & 87.5 \\
\hline 25 & 3 & 2 & 3 & 2 & 3 & 2 & 3 & 2 & 2 & 1 & 23 & 57.5 \\
\hline 26 & 2 & 3 & 3 & 1 & 4 & 2 & 4 & 4 & 4 & 2 & 29 & 72.5 \\
\hline 27 & 3 & 2 & 3 & 3 & 4 & 2 & 3 & 3 & 4 & 0 & 27 & 67.5 \\
\hline 28 & 4 & 3 & 3 & 2 & 3 & 3 & 4 & 3 & 3 & 3 & 31 & 77.5 \\
\hline 29 & 3 & 0 & 2 & 1 & 4 & 1 & 2 & 3 & 0 & 0 & 16 & 40 \\
\hline 30 & 4 & 2 & 4 & 2 & 4 & 2 & 2 & 2 & 4 & 3 & 29 & 72.5 \\
\hline & & & & & & & & & & & & 2147.5 \\
\hline
\end{tabular}




\section{c. Calculation Chart Results Using the SUS Formula}

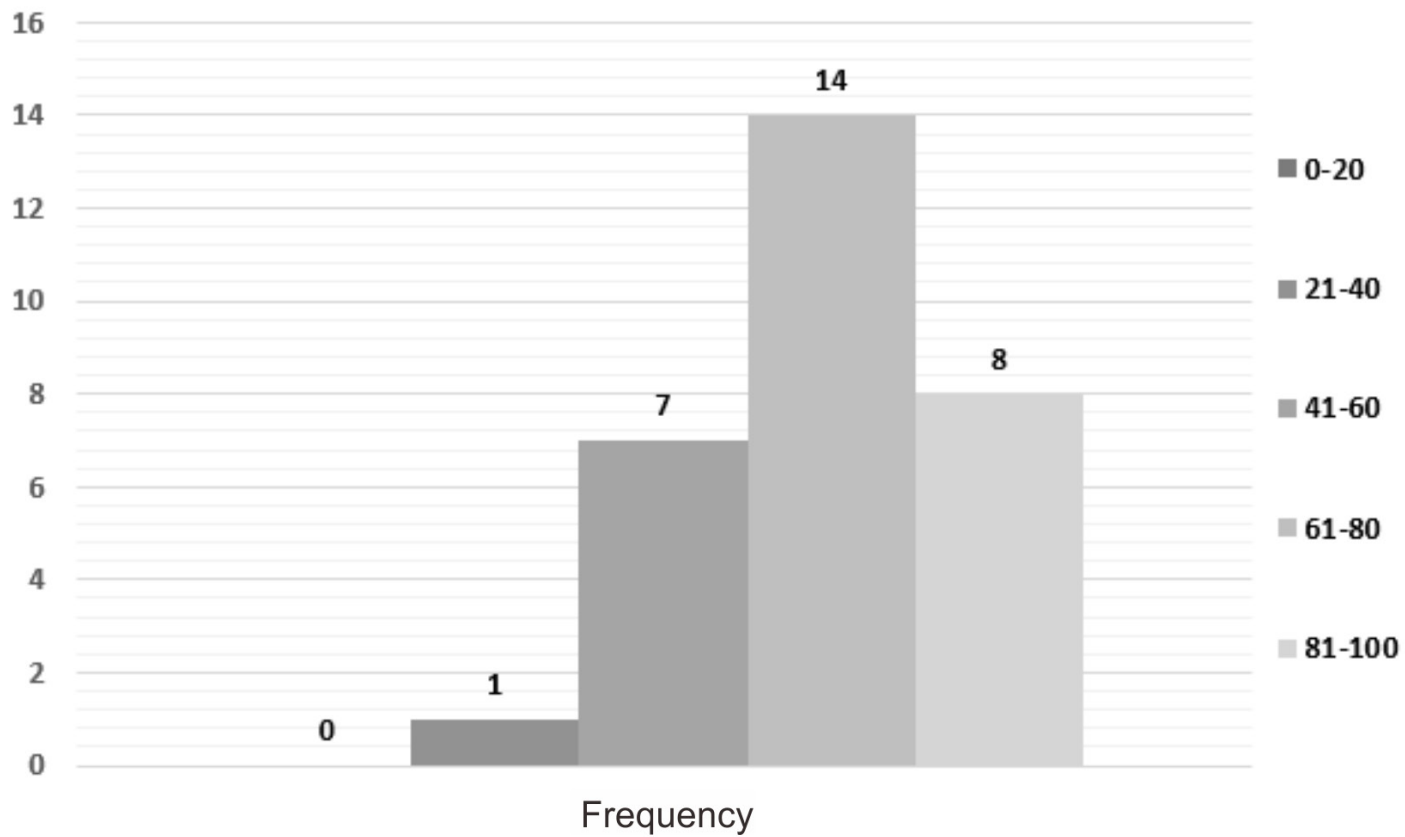

Figure 11. Calculation graph with the SUS formula

The formula for calculating the average value using Equation (2):

$$
\text { Average Value }=\sum_{i=1}^{n} \frac{x_{i}}{N}
$$

Where xi is: Respondent Score Value, and N: Number of Respondents

The average value $=2147.5 / 30=71.58$

Calculation of the average value using Equation 2 yields 71.58 . This is within the range of $61-80$, which is "good".

\section{Conclusions}

Edu Game based on Virtual Reality "Earth Hero" can increase knowledge about environmental pollution in students aged 10-13 years. Based on the black box test, this educational game can run according to its function. And based on the usability test using the SUS calculation formula, the game "Earth Hero" gets "good" criteria.

\section{References}

[1] H. Supriyono, A. N. Saputra, and E. Sudarmilah, "Rancang bangun aplikasi pembelajaran hadis untuk perangkat mobile berbasis android," $J$. Inform., vol. 8, no. 2, pp. 907-920, 2014.

[2] E. Sudarmilah and M. G. Negara, "Augmented Reality Edu Game Senjata Tradisional Indonesia," Khazanah Inform., vol. 1, no. 1, pp. 12-15, 2015.

[3] E. Sudarmilah, H. Supriyono, F. Yasin, A. Irsyadi, and A. Fatmawati, "Prototyping AR Edu Game untuk anak-anak: belajar budaya Indonesia," MATEC Web Konf. 197, 03012 AASEC 2018, vol. 03012, pp. 2-5, 2018.

[4] L. Sigit, M. Dicky, and S. Hendri, "Penerapan Algoritme Fisher Yates pada Game Edukasi Eco Mania Berbasis Unity 3D,” no. x, pp. 1-12, 2015.

[5] Z. Tuma, J. Tuma, R. Knoflíček, P. Blecha, and F. Bradác, "The Process Simulation Using by Virtual Reality," Procedia Eng., vol. 69, pp. 1015-1020, 2014.

[6] F. Setiawan Riyadi, A. Sumarudin, and M. Sari Bunga, "Aplikasi 3D Virtual Reality Sebagai Media Pengenalan Kampus Politeknik Negeri Indramayu Berbasis Mobile," J. Inform. dan Komput., vol. 2, no. 2, pp. 75-82, 2017.

[7] Ismiyati, D. Marlita, and D. Saidah, "Pencemaran Udara Akibat Emisi Gas Buang Kendaraan Bermotor," J. Manaj. Transp. Logistik, vol. 01, no. 03, pp. 241-248, 2014.

[8] M. Haward, "Plastic pollution of the world's seas and oceans as a contemporary challenge in ocean governance," Nat. Commun., vol. 9, no. 1, pp. 9-11, 2018.

[9] Y. dan U. Firmansyah, "Penerapan Metode SDLC Waterfall Dalam Pembuatan Sistem Informasi Akademik Berbasis Web Studi Kasus Pondok Pesantren Al-Habi Sholeh Kabupaten Kubu Raya , Kalimantan Barat," J. Teknol. Manaj. Inform., vol. 4, no. 1, pp. 185-191, 2018.

[10] R. Scroggins, "SDLC and Development Methodologies," Glob. J. Comput. Sci. Technol. C 
Softw. Data Eng., vol. 14, no. 7, pp. 0-2, 2014.

[11] M. A. Zaus, R. E. Wulansari, S. Islami, and D. Pernanda, "Perancangan Media Pembelajaran Listrik Statis dan Dinamis Berbasis Android," INTECOMS J. Inf. Technol. Comput. Sci., vol. 1, no. 1, pp. 1-7, 2018.

[12] U. Al Faruq, "Rancang Bangun Aplikasi Rekam Medis Poliklinik Universitas Trilogi,” J. Inform., vol. 9, no. 1, pp. 1017-1027, 2017.

[13] W. A. Kusuma, V. Noviasari, and G. I. Marthasari, "Analisis Usability dalam User Experience pada Sistem KRS Online UMM menggunakan USE Questionnaire," J. Nas. Tek. Elektro dan Teknol. Inf., vol. 5, no. 4, pp. 294-301, 2017.

[14] A. Mufa and E. Sudarmilah, "Game Anti Narkoba Berbasis Multi-Platform," Khazanah Inform., vol. 2, no. 2, pp. 95-98, 2016.

[15] M. Fadhli, "Pengembangan Media Pembelajaran Berbasis Video Kelas IV Sekolah Dasar," J. Dimens. Pendidik. dan Pembelajaran, vol. 3, no. 1, pp. 24-29, 2015.

[16] H. Supriyono, R. F. Rahmadzani, M. S. Adhantoro, and A. K. Susilo, "Rancang Bangun Media Pembelajaran Dan Game Edukatif Pengenalan Aksara Jawa 'Pandawa ," Pros. 4thUniversity Res. Colloq. 2016, pp. 1-12, 2016.

[17] R. A. Zulfikar and A. A. Supianto, "Rancang Bangun Aplikasi Antrian Poliklinik Berbasis Mobile," J. Teknol. Inf. dan Ilmu Komput., vol. 5, no. 3, p. 361, 2018.

[18] M. S. Mustaqbal, R. F. Firdaus, and H. Rahmadi, "Pengujian Aplikasi Menggunakan Black Box Testing Boundary Value Analysis," J. Ilm. Teknol. Inf. Terap., vol. I, no. 3, pp. 31-36, 2015.

[19] M. Kumar, S. K. Singh, and R. . Dwivedi, "A Comparative Study of Black Box Testing and White Box Testing Techniques," Int. J. Adv. Res. Comput. Sci. Manag. Stud., vol. 3, no. 10, pp. 3244, 2015.

[20] E. Febriyanto, U. Rahardja, A. Faturahman, and N. Lutfiani, "Sistem Verifikasi Sertifikat Menggunakan Qrcode Pada Central Event Information," Techno.COM, vol. 18, no. 1, pp. 50-63, 2019.

[21] S. M. Muyasaroh and E. Sudarmilah, "Game Edukasi Mitigasi Bencana Kebakaran Berbasis Android," J. PROtek, vol. 06, no. 1, pp. 31-35, 2019. 